\title{
Assignment of 'Alteromonas marinoglutinosa' NCIMB 1770 to Pseudoalteromonas mariniglutinosa sp. nov., nom. rev., comb. nov.
}

\author{
Lyudmila A. Romanenko, ${ }^{1}$ Natalia V. Zhukova, ${ }^{2}$ Anatoly M. Lysenko, ${ }^{3}$ \\ Valery V. Mikhailov ${ }^{1}$ and Erko Stackebrandt ${ }^{4}$
}

Correspondence Erko Stackebrandt erko@dsmz.de

\author{
${ }^{1}$ Pacific Institute of Bioorganic Chemistry, Far-Eastern Branch, Russian Academy of Sciences, \\ 690022 Vladivostok, Prospekt 100 Let Vladivostoku, 159, Russia \\ ${ }^{2}$ Institute of Marine Biology, Far-Eastern Branch, Russian Academy of Sciences, 690041 \\ Vladivostok, Russia \\ ${ }^{3}$ Institute of Microbiology, Russian Academy of Sciences, 117811 Moscow, Russia \\ ${ }^{4}$ DSMZ - Deutsche Sammlung von Mikroorganismen und Zellkulturen, Mascheroder Weg $1 \mathrm{~b}$ \\ D-38124 Braunschweig, Germany
}

\begin{abstract}
The taxonomic position of the marine bacterium 'Alteromonas marinoglutinosa' NCIMB 1770 was investigated in a polyphasic study. Analysis of $16 \mathrm{~S}$ rDNA sequence and DNA-DNA reassociation values confirmed the phylogenetic position of strain NCIMB 1770 within the genus Pseudoalteromonas as a separate species, distinct from all Pseudoalteromonas species with validly described names. On the basis of physiological and molecular properties, it is proposed that strain NCIMB 1770 is classified as Pseudoalteromonas mariniglutinosa sp. nov., nom. rev., comb.

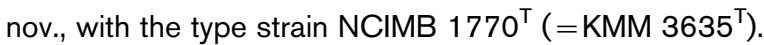

The genus Alteromonas, originally described by Baumann et al. (1972), was revised (Gauthier et al., 1995) with the creation of two genera: Alteromonas (containing a single species, Alteromonas macleodii) and Pseudoalteromonas (including the 12 remaining species that previously belonged to the genus Alteromonas). In the following years, several novel species have been classified as members of the genus Pseudoalteromonas, which (at the time of writing) comprises 29 species with validly described names, including the recently described species Pseudoalteromonas issachenkonii (Ivanova et al., 2002a), Pseudoalteromonas ruthenica (Ivanova et al., 2002b), Pseudoalteromonas maricaloris and Pseudoalteromonas flavipulchra (Ivanova et al., 2002c), Pseudoalteromonas translucida and Pseudoalteromonas paragorgicola (Ivanova et al., 2002d), Pseudoalteromonas agarivorans (Romanenko et al., 2003) and Pseudoalteromonas phenolica (Isnansetyo \& Kamei, 2003).

Strain NCIMB 1770 was isolated from the diatom Chaetoceros lauderi, collected from sea water of the Marseille Gulf (Berland et al., 1969). The strain was identified as 'Pseudomonas marinoglutinosa' on the basis of its phenotypic features, which were originally described by

Published online ahead of print on 13 January 2003 as DOI 10.1099/ ijs.0.02564-0.

The GenBank/EMBL/DDBJ accession number for the 16S rDNA sequence of NCIMB $1770^{\top}$ is AJ507251.
ZoBell \& Allen (1935) for another marine agarolytic bacterium named 'Pseudomonas marinoglutinosa'. DNArRNA hybridization experiments revealed that ' $P$. marinoglutinosa' NCIMB 1770 should be assigned to the genus Alteromonas (De Vos et al., 1989). Strain NCIMB 1770 was not included in the phylogenetic study that led to the description of the genus Pseudoalteromonas (Gauthier et al., 1995), hence its taxonomic status was not specified. In the present study, strain NCIMB 1770 was subjected to biochemical and molecular analyses to clarify its taxonomic position. On the basis of phenotypic and molecular properties, Pseudoalteromonas mariniglutinosa sp. nov., nom. rev., comb. nov. is proposed.

Strain 'Alteromonas marinoglutinosa' NCIMB 1770 was received from the National Collection of Industrial and Marine Bacteria, Aberdeen, UK. It was grown routinely on Marine 2216 Agar (MA), Marine Broth (MB) (both Difco) and nutrient sea-water-containing medium (SWM) at $28^{\circ} \mathrm{C}$. The composition of SWM was as follows $\left(\mathrm{g} \mathrm{l}^{-1}\right)$ : peptone, $5 \cdot 0$; yeast extract, $2 \cdot 5$; glucose, $1 \cdot 0 ; \mathrm{K}_{2} \mathrm{HPO}_{4}, 0 \cdot 2$; $\mathrm{MgSO}_{4}, 0 \cdot 05$; agar, $15 \cdot 0$; sea water, $750 \mathrm{ml}$ and distilled water, $250 \mathrm{ml}$. The bacterium was stored at $-70{ }^{\circ} \mathrm{C}$ in liquid nutrient medium that was supplemented with $30 \%(\mathrm{v} / \mathrm{v})$ glycerol. Phenotypic properties, including Gram-staining, oxidase, catalase, gelatinase, caseinase, lipase, DNase, amylase and chitinase activities, were tested as described by Smibert \& Krieg (1994) and Baumann et al. (1972), by 
using MA or SWM as basal media. Hydrolysis of $\kappa$ carrageenan was determined as described by Yaphe \& Baxter (1955). Growth at $4-45^{\circ} \mathrm{C}$ and $\mathrm{pH} 5 \cdot 0-10 \cdot 0$ was examined on $\mathrm{MA}$ and in $\mathrm{MB}$, respectively. Sea-water requirement and tolerance of $0-15 \% \mathrm{NaCl}$ were determined using nutrient medium prepared on the artificial sea-water base, supplemented with appropriate amounts of $\mathrm{NaCl}$. The medium of Leifson (1963) was used to test acid production from sugars, with $1 \%(\mathrm{w} / \mathrm{v})$ of each test sugar. The agar-diffusion method was applied to test antibiotic sensitivity on MA plates, by using discs impregnated with antibiotics (per disc): ampicillin, $10 \mu \mathrm{g}$; benzylpenicillin, $10 \mathrm{U}$; gentamicin, $10 \mu \mathrm{g}$; kanamycin, $30 \mu \mathrm{g}$, erythromycin, $30 \mu \mathrm{g}$; carbenicillin, $25 \mu \mathrm{g}$; lincomycin, $15 \mu \mathrm{g}$; oleandomycin, $15 \mu \mathrm{g}$; polymyxin, $300 \mathrm{U}$; streptomycin, $30 \mu \mathrm{g}$; tetracycline, $30 \mu \mathrm{g} ; \mathrm{O} / 129,150 \mu \mathrm{g}$; and neomycin, $15 \mu \mathrm{g}$. Phenotypic characteristics were additionally determined by using API $20 \mathrm{NE}$ and API ZYM galleries (bioMérieux) and the Biolog GN identification system as recommended by the manufacturers, except that the culture was suspended in $3 \%(\mathrm{w} / \mathrm{v}) \mathrm{NaCl}$ solution. Motility was examined by the hanging-drop method. Cell morphology was examined by transmission electron microscopy of exponential-phase cells grown on MA. DNA G + C content was determined by the methods described by Marmur \& Doty (1962) and Owen et al. (1969). DNA-DNA hybridization was performed by the initial reassociation rate kinetic method of De Ley et al. (1970). Cellular fatty acid and lipid compositions were identified as described by Svetashev et al. (1995) and Ivanova et al. (2000b). The 16S rRNA gene sequence was determined as described by Rainey et al. (1996). The 16S rDNA sequence of strain NCIMB 1770 was aligned manually with nucleotide sequences obtained from GenBank/EMBL and phylogenetic dendrograms were constructed by using different treeing algorithms [distance matrix (DeSoete, 1983; Felsenstein, 1993) and neighbourjoining (Felsenstein, 1993)].

16S rDNA similarity values between strain NCIMB 1770 and Pseudoalteromonas prydzensis ACAM $620^{\mathrm{T}}$ (99.3\%) were high, while those with several type strains of the genus Pseudoalteromonas were lower by about $1 \%$, i.e. Pseudoalteromonas atlantica IAM $12376^{\mathrm{T}}(98 \cdot 2 \%)$, P. issachenkonii KMM $3549^{\mathrm{T}}(98 \cdot 2 \%)$, Pseudoalteromonas espejiana NCIMB $2127^{\mathrm{T}}(98 \cdot 2 \%)$, Pseudoalteromonas distincta KMM $638^{\mathrm{T}}$ $(98 \cdot 1 \%)$, Pseudoalteromonas elyakovii KMM $162^{\mathrm{T}}(98 \cdot 1 \%)$, P. agarivorans $\mathrm{KMM} 255^{\mathrm{T}}(98 \cdot 1 \%)$, Pseudoalteromonas carrageenovora IAM $12662^{\mathrm{T}}(98 \cdot 1 \%)$, Pseudoalteromonas haloplanktis ATCC $14393^{\mathrm{T}}(98.0 \%), \quad$ Pseudoalteromonas nigrifaciens NCIMB $8614^{\mathrm{T}}(98.0 \%)$, Pseudoalteromonas undina NCIMB $2128^{\mathrm{T}}$ (98.0\%), Pseudoalteromonas tetraodonis IAM $14160^{\mathrm{T}}$ (98.0\%) and P. antarctica CECT $4664^{\mathrm{T}}(97 \cdot 7 \%)$. Type strains of the other species of the genus are less closely related to strain NCIMB 1770. The phylogenetic position of strain NCIMB 1770, obtained by two different algorithms, agrees in the order of the major branches. The statistical significance of the majority of these branching points is confirmed by high bootstrap values. The resolution of lineages defined by highly related organisms is

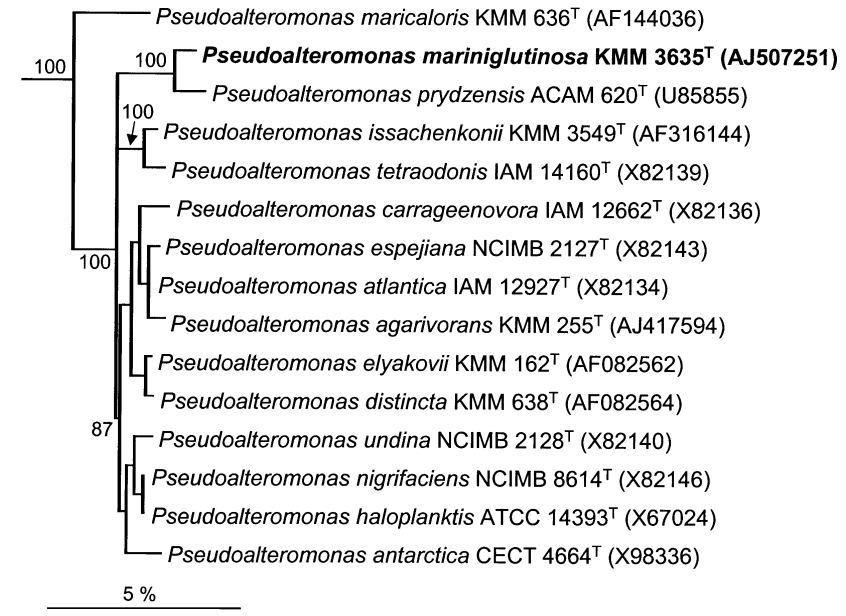

Fig. 1. Neighbour-joining analysis of $16 \mathrm{~S}$ rRNA gene sequences, showing the position of strain $\mathrm{KMM} 3635^{\mathrm{T}}$ (=NCIMB $1770^{\top}$ ) among phylogenetically closely related Pseudoalteromonas species. Less related Pseudoalteromonas species served as the root (only one type strain is shown). Numbers at branching points refer to bootstrap analyses (percentage of 500 resamplings). Bar, 5 nucleotide substitutions per 100 nucleotides.

poor, and is not supported by high bootstrap values. Fig. 1 depicts a neighbour-joining dendrogram (Felsenstein, 1993).

Strain NCIMB 1770 was aerobic, Gram-negative, nonpigmented, motile by a single polar flagellum and capable of agar and carrageenan hydrolysis. The strain required $\mathrm{Na}^{+}$ ions for growth and grew in 1-9\% $\mathrm{NaCl}$. The temperature range for growth was $5-37^{\circ} \mathrm{C}$; growth was not detected at $40^{\circ} \mathrm{C}$. On complex marine media, agarolytic, smooth, convex, slimy, non-pigmented colonies were formed. Two types of colonies, either whitish or translucent, were homogeneous with respect to metabolic properties and were considered to be variants.

Strain NCIMB 1770 was positive for oxidase, catalase, lipase, caseinase, DNase and gelatinase activities and starch, agar and carrageenan decomposition, when tests were performed by conventional methods. It should be noted that the API ZYM test revealed negative reactions for $\alpha$-galactosidase and $\beta$-galactosidase, whereas agarolytic activity was detectable by routine methods. The main phenotypic features of strain NCIMB 1770 and some phylogenetically related species are displayed in Table 1.

Major fatty acids were $\mathrm{C}_{16: 0}(24 \cdot 0 \%), \mathrm{C}_{16: 1} \omega 7 c(38 \cdot 9 \%)$ and $\mathrm{C}_{17: 1} \omega 8 c(9 \cdot 4 \%)$. The following were present in smaller amounts $(>1 \cdot 5 \%)$ : $\mathrm{C}_{14: 0}(1 \cdot 7 \%), \mathrm{C}_{15: 0}(3.9 \%)$, iso- $\mathrm{C}_{16: 0}$ $(2 \cdot 8 \%), \mathrm{C}_{17: 0}(3 \cdot 9 \%)$ and $\mathrm{C}_{18: 1} \omega 7 \mathrm{c}(5 \cdot 9 \%)$. As traces $(<1.0 \%)$, the following fatty acids were present: $\mathrm{C}_{11: 0}$, $\mathrm{C}_{12: 1}$, iso- $\mathrm{C}_{13: 0}, \mathrm{C}_{13: 0}, \mathrm{C}_{13: 1}$, iso- $\mathrm{C}_{14: 0}, \mathrm{C}_{14: 1} \omega 7 c, \mathrm{C}_{14: 0}$, iso- $\mathrm{C}_{15: 0}$, anteiso- $\mathrm{C}_{15: 0}, \mathrm{C}_{15: 1} \omega 6 c, \mathrm{C}_{11: 0} 3-\mathrm{OH}, \mathrm{C}_{16: 1} \omega 5 c$, $\mathrm{C}_{12: 0} \quad 3-\mathrm{OH}, \quad$ iso- $\mathrm{C}_{17: 0}, \mathrm{C}_{17: 1} \omega 6 c$, iso- $\mathrm{C}_{18: 0}, \mathrm{C}_{18: 0}$, 
Table 1. Phenotypic characteristics of $P$. mariniglutinosa NCIMB $1770^{\top}$ and related Pseudoalteromonas species

Taxa: 1, P. mariniglutinosa; 2, P. atlantica; 3, P. carrageenovora; 4, P. elyakovii; 5, P. prydzensis; 6, P. issachenkonii; 7, P. agarivorans; 8, P. espejiana; 9, P. distincta; 10, P. haloplanktis; 11, P. nigrifaciens; 12, P. undina; 13, P. tetraodonis; 14, P. antarctica. Data were taken from Chan et al. (1978); Baumann et al. (1984); Akagawa-Matsushita et al. (1992); Bozal et al. (1997); Bowman (1998); Ivanova et al. (1996, 2000a, 2001, 2002a); Sawabe et al. (2000); Romanenko et al. (2003). +, Positive test reaction; -, negative test reaction; V, variable results between strains; W, weak reaction; ND, not determined. All strains were positive for the following tests: $\mathrm{Na}^{+}$requirement for growth, growth at $10-30{ }^{\circ} \mathrm{C}$, motility, oxidase and catalase activities and production of gelatinase. All strains were negative for growth at $40{ }^{\circ} \mathrm{C}$, indole production and arginine dihydrolase activity.

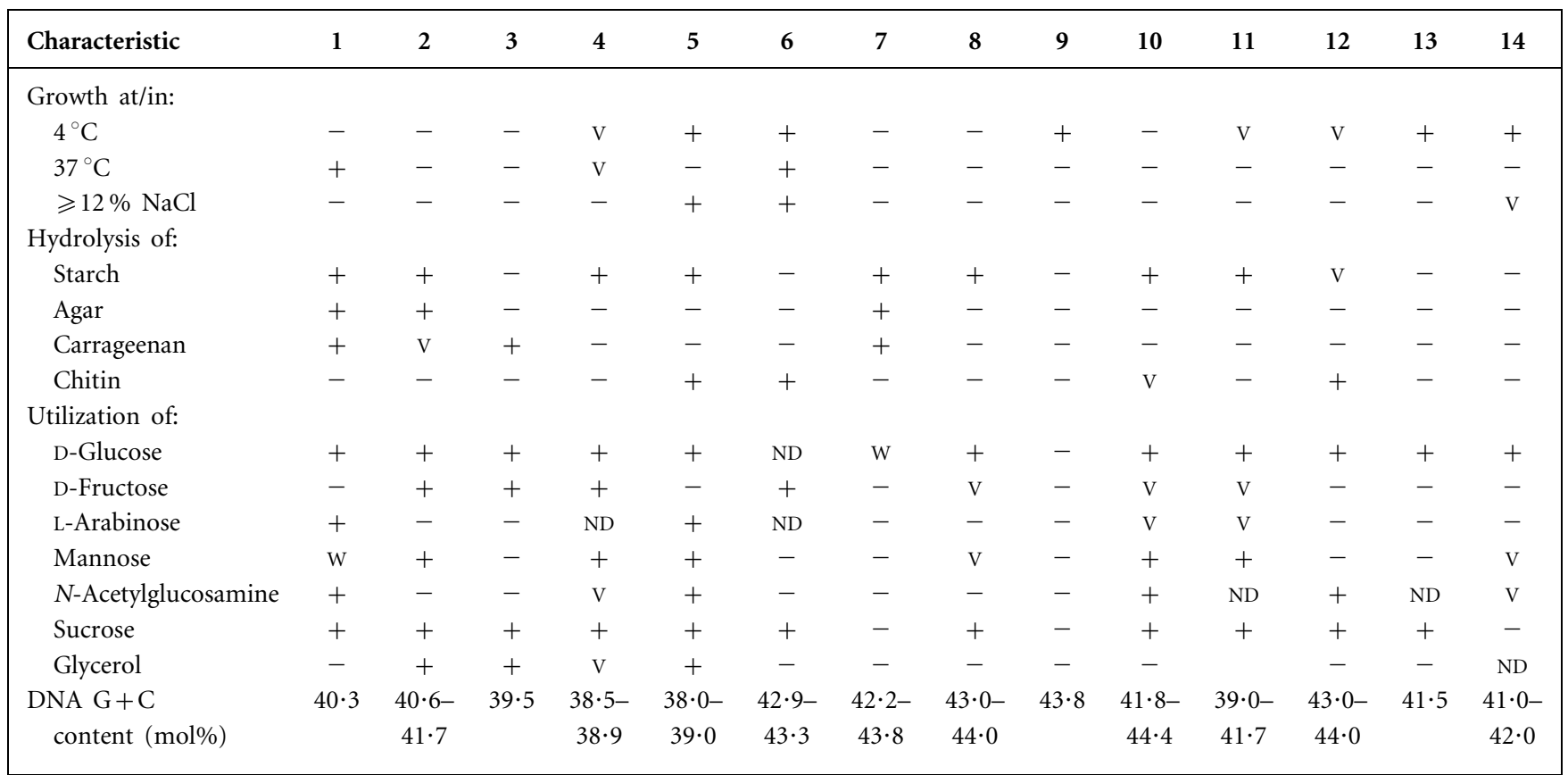

$\mathrm{C}_{18: 1} \omega 11 c, \mathrm{C}_{18: 1} \omega 9 c, \mathrm{C}_{19: 1}, \mathrm{C}_{12: 0}, \mathrm{C}_{15: 1} \omega 8 c$ and anteiso$\mathrm{C}_{17: 0}$. Phospholipids included phosphatidylethanolamine $(67 \cdot 1 \%)$, phosphatidylglycerol $(28 \cdot 6 \%)$, diphosphatidylglycerol (DPG; $3 \cdot 2 \%$ ) and bis-phosphatidic acid $(1 \cdot 2 \%)$. The presence of smaller amounts of DPG in P. nigrifaciens and $P$. agarivorans $(1 \cdot 4$ and $0 \cdot 9-1 \cdot 3 \%$, respectively) has been reported previously by Frolova et al. (2000) and Romanenko et al. (2003).

16S rDNA sequence analysis (1483 nucleotides) revealed that strain NCIMB 1770 is a member of the genus Pseudoalteromonas. Except for P. prydzensis, with which $99 \cdot 3 \%$ sequence similarity was shared, all other species had similarity values lower than $98 \cdot 2 \%$. Previous DNADNA reassociation studies on the phylogenetically closely related type strains depicted in Fig. 1 revealed that DNA relatedness values were significantly lower than $70 \%$ (Ivanova et al., 2000a; Mikhailov et al., 2002; Romanenko et al., 2003). Thus, 97.5\% 16S rRNA gene similarity, indicated to be the threshold value above which it has been advised to perform DNA-DNA reassociation studies to determine species status (Stackebrandt \& Goebel, 1994), is clearly higher for members of the genus Pseudoalteromonas and should be set to $99 \cdot 0 \%$. A similar situation has recently been observed for the actinobacterial genus Amycolatopsis (Wink et al., 2003). Although closely related by $99 \cdot 3 \% 16 \mathrm{~S}$
rRNA gene similarity, strain NCIMB 1770 and its closest phylogenetic relative, $P$. prydzensis ACAM $620^{\mathrm{T}}$, share only $35 \%$ DNA-DNA similarity. A selection of nine type strains from the phylogenetically closely related cluster (Fig. 1) confirmed the low DNA-DNA similarity value obtained with strain NCIMB 1770, i.e. similarities with P. elyakovii KMM $162^{\mathrm{T}}$ (45\%), P. carrageenovora IAM $12662^{\mathrm{T}}(32 \%)$, $P$. undina IAM $12922^{\mathrm{T}}(42 \%)$, P. distincta KMM $638^{\mathrm{T}}$ (42\%), P. espejiana IAM $13640^{\mathrm{T}}(16 \%)$, P. haloplanktis IAM $12915^{\mathrm{T}}(15 \%)$, P. tetraodonis IAM $14160^{\mathrm{T}}(28 \%)$, $P$. atlantica IAM $12376^{\mathrm{T}}(28 \%)$ and $P$. agarivorans $\mathrm{KMM}$ $255^{\mathrm{T}}(16 \%)$ were well below $50 \%$ ( $P$. antarctica CECT $4664^{\mathrm{T}}$ is a patented strain and has not been released for this study). Such low DNA-DNA similarity data indicate that strain NCIMB 1770 does not belong to any previously described species (Wayne et al., 1987). On the basis of the results obtained from the present study, strain 'Alteromonas marinoglutinosa' NCIMB 1770 is proposed as the type strain of a novel species, Pseudoalteromonas mariniglutinosa sp. nov., nom. rev., comb. nov.

Strain NCIMB $1770^{\mathrm{T}}$ shared some common properties with $P$. atlantica, $P$. carrageenovora and $P$. agarivorans in the hydrolysis of starch, agar and carrageenan, but differed from these species in growth at $37^{\circ} \mathrm{C}$ and physiological properties. Growth at $37^{\circ} \mathrm{C}$ is shared with P. issachenkonii 
and some strains of P. elyakovii. Differences in metabolic properties, such as hydrolysis of starch, agar, carrageenan and chitin, as well as the utilization of glucose, L-arabinose, sucrose and $\mathrm{N}$-acetylglucosamine and frequently the DNA $\mathrm{G}+\mathrm{C}$ content, allow the discrimination of strain NCIMB $1770^{\mathrm{T}}$ from other phylogenetically closely related species (Table 1).

\section{Description of Pseudoalteromonas mariniglutinosa sp. nov., nom. rev., comb. nov.}

Pseudoalteromonas mariniglutinosa (ma.ri.ni.glu.ti.no'sa. L. adj. marinus of the sea; L. adj. glutinosa glutinous, slimy; N.L. fem. adj. mariniglutinosa from the sea, forming glutinous, slimy colonies).

Gram-negative, strictly aerobic, rod-shaped cells, $0 \cdot 6-0 \cdot 8$ $\mu \mathrm{m}$ in diameter and $1 \cdot 7-2 \cdot 0 \mu \mathrm{m}$ in length, motile by a single, polar, unsheathed flagellum. Endospores are not formed. Oxidase- and catalase-positive. $\mathrm{Na}^{+}$is essential for growth; growth is observed in $1-9 \% \mathrm{NaCl}$. Mesophilic and neutrophilic chemo-organotroph. Grows at $5-37^{\circ} \mathrm{C}$ with optimal growth at $20-28^{\circ} \mathrm{C}$; no growth at 4 or $40^{\circ} \mathrm{C}$. On complex marine media, smooth, convex, slimy, nonpigmented, whitish or translucent colonies that are depressed into the agar are formed. In addition to the phenotypic characters indicated in Table 1, the type strain exhibits the following reactions: acid is produced from sucrose, maltose, L-arabinose and D-mannitol by using Leifson's method; acid is not produced from glucose, lactose, mannose, D-galactose, D-xylose, melibiose, rhamnose or glycerol. L-Malate, citrate, propionate and L-serine are utilized, whereas caprate and butyrate are not. DNase activity is positive. According to the API 20 NE panel, the following tests are positive: aesculin and gelatin hydrolysis, assimilation of glucose, arabinose, mannose (weakly), mannitol, $N$-acetylglucosamine, maltose, malate and citrate. The following tests are negative: nitrate reduction, indole production, arginine dihydrolase and urease activities, $p$ nitrophenyl-D-galactopyranoside (PNPG) test, gluconate, caprate, adipate and phenylacetate assimilation. In API ZYM analysis, strain NCIMB $1770^{\mathrm{T}}$ exhibits positive reactions for alkaline phosphatase, esterase-lipase C8 (weakly), leucine arylamidase, acid phosphatase, naphthol-AS-BIphosphohydrolase and $N$-acetyl- $\beta$-glucosaminidase. Negative reactions are observed for esterase (C4), lipase (C14), valine arylamidase, cystine arylamidase, trypsin, $\alpha$-chymotrypsin, $\alpha$-galactosidase, $\beta$-galactosidase, $\beta$-glucuronidase, $\alpha$-glucosidase, $\beta$-glucosidase, $\alpha$-mannosidase and $\alpha$-fucosidase. As shown by Biolog GN MicroPlate tests, the type strain utilizes $\alpha$-cyclodextran, dextran, $N$-acetyl-D-glucosamine, $\alpha$-Dglucose, D-mannitol, D-mannose, methylpyruvate, monomethylsuccinate, acetic acid, citric acid, DL-lactic acid, propionic acid, succinic acid, L-glutamic acid, L-proline (weak) and L-serine. Negative reactions are observed for utilization of the other organic compounds included in Biolog GN MicroPlate tests. Susceptible to streptomycin, polymyxin, gentamicin (weakly), kanamycin, carbenicillin and neomycin, but resistant to ampicillin, oleandomycin, lincomycin, benzylpenicillin, $\mathrm{O} / 129$, oxacillin and tetracycline. Major fatty acids are $\mathrm{C}_{16: 0}, \mathrm{C}_{16: 1} \omega 7 c$ and $\mathrm{C}_{17: 1} \omega 8 c$. Phospholipids include phosphatidylethanolamine and phosphatidylglycerol as main components and diphosphatidylglycerol and bis-phosphatidic acid as minor components. The DNA G $+\mathrm{C}$ content is $40.3 \mathrm{~mol} \%$ (thermal denaturation method).

The type strain, NCIMB $1770^{\mathrm{T}}\left(=\mathrm{KMM} 3635^{\mathrm{T}}\right)$, was isolated from the diatom Chaetoceros lauderi.

\section{Acknowledgements}

The authors thank Ina Kramer and Jolantha Swiderski for excellent technical assistance in $16 \mathrm{~S}$ rDNA sequencing and data analysis. Dr Susanne Verbarg and Mrs Anja Frühling are acknowledged for supporting the API and Biolog GN tests. We are grateful to Carol Nichols and John P. Bowman (ACAM, Australian Collection of Antarctic Micro-organisms, Antarctic CRC, University of Tasmania, Hobart, Tasmania, Australia) for the gift of P. prydzensis ACAM $620^{\mathrm{T}}$. This study was supported in part by grant no. 02-04-49517 from the Russian Foundation for Basic Research and by grant no. 95-03-19/0203-19 from the Ministry for Industry and Science (MIS) of the Russian Federation (RF).

\section{References}

Akagawa-Matsushita, M., Matsuo, M., Koga, Y. \& Yamasato, K. (1992). Alteromonas atlantica sp. nov. and Alteromonas carrageenovora sp. nov., bacteria that decompose algal polysaccharides. Int J Syst Bacteriol 42, 621-627.

Baumann, L., Baumann, P., Mandel, M. \& Allen, R. D. (1972). Taxonomy of aerobic marine eubacteria. J Bacteriol 3, 402-429.

Baumann, P., Baumann, L., Bowditch, R. D. \& Beaman, B. (1984). Taxonomy of Alteromonas: A. nigrifaciens sp. nov., nom. rev.; A. macleodii; and A. haloplanktis. Int J Syst Bacteriol 34, 145-149.

Berland, B. R., Bianchi, M. G. \& Maestrini, S. Y. (1969). Etude des bactéries associées aux Algues marines en culture. I. Détermination préliminaire des espèces. Mar Biol 2, 350-355 (in French).

Bowman, J. P. (1998). Pseudoalteromonas prydzensis sp. nov., a psychrotrophic, halotolerant bacterium from Antarctic sea ice. Int J Syst Bacteriol 48, 1037-1041.

Bozal, N., Tudela, E., Rosselló-Mora, R., Lalucat, J. \& Guinea, J. (1997). Pseudoalteromonas antarctica sp. nov., isolated from an Antarctic coastal environment. Int J Syst Bacteriol 47, 345-351.

Chan, K. Y., Baumann, L., Garza, M. M. \& Baumann, P. (1978). Two new species of Alteromonas: Alteromonas espejiana and Alteromonas undina. Int J Syst Bacteriol 28, 217-222.

De Ley, J., Cattoir, H. \& Reynaerts, A. (1970). The quantitative measurement of DNA hybridization from renaturation rates. Eur J Biochem 12, 133-142.

DeSoete, G. (1983). A least squares algorithm for fitting additive trees to proximity data. Psychometrika 48, 621-626.

De Vos, P., Van Landschoot, A., Segers, P. \& 9 other authors (1989). Genotypic relationships and taxonomic localization of unclassified Pseudomonas and Pseudomonas-like strains by deoxyribonucleic acid:ribosomal ribonucleic acid hybridizations. Int $J$ Syst Bacteriol 39, 35-49.

Felsenstein, J. (1993). PHYLIP (phylogenetic inference package) version 3.5.1. Department of Genetics, University of Washington, Seattle, USA. 
Frolova, G. M., Kurilenko, V. V., Ivanova, E. P., Gorshkova, N. M. \& Mikhailov, V. V. (2000). Phospholipids of marine proteobacteria of the genus Pseudoalteromonas. Mikrobiologiya 69, 506-510 (in Russian).

Gauthier, G., Gauthier, M. \& Christen, R. (1995). Phylogenetic analysis of the genera Alteromonas, Shewanella, and Moritella using genes coding for small-subunit rRNA sequences and division of the genus Alteromonas into two genera, Alteromonas (emended) and Pseudoalteromonas gen. nov., and proposal of twelve new species combinations. Int J Syst Bacteriol 45, 755-761.

Isnansetyo, A. \& Kamei, Y. (2003). Pseudoalteromonas phenolica sp. nov., a novel marine bacterium that produces phenolic antimethicillin-resistant Staphylococcus aureus substances. Int J Syst Evol Microbiol 53, 583-588.

Ivanova, E. P., Kiprianova, E. A., Mikhailov, V. V., Levanova, G. F., Garagulya, A. D., Gorshkova, N. M., Yumoto, N. \& Yoshikawa, S. (1996). Characterization and identification of marine Alteromonas nigrifaciens strains and emendation of the description. Int J Syst Bacteriol 46, 223-228.

Ivanova, E. P., Chun, J., Romanenko, L. A., Matte, M. E., Mikhailov, V. V., Frolova, G. M., Huq, A. \& Colwell, R. R. (2000a). Reclassification of Alteromonas distincta Romanenko et al. 1995 as Pseudoalteromonas distincta comb. nov. Int J Syst Evol Microbiol 50, 141-144.

Ivanova, E. P., Zhukova, N. V., Svetashev, V. I., Gorshkova, N. M., Kurilenko, V. V., Frolova, G. M. \& Mikhailov, V. V. (2000b). Evaluation of phospholipid and fatty acid compositions as chemotaxonomic markers of Alteromonas-like Proteobacteria. Curr Microbiol 41, 341-345.

Ivanova, E. P., Romanenko, L. A., Matté, M. H. \& 10 other authors (2001). Retrieval of the species Alteromonas tetraodonis Simidu et al. 1990 as Pseudoalteromonas tetraodonis comb. nov. and emendation of description. Int J Syst Evol Microbiol 51, 1071-1078.

Ivanova, E. P., Sawabe, T., Alexeeva, Y. V., Lysenko, A. M., Gorshkova, N. M., Hayashi, K., Zukova, N. V., Christen, R. \& Mikhailov, V. V. (2002a). Pseudoalteromonas issachenkonii sp. nov., a bacterium that degrades the thallus of the brown alga Fucus evanescens. Int J Syst Evol Microbiol 52, 229-234.

Ivanova, E. P., Sawabe, T., Lysenko, A. M. \& 8 other authors (2002b). Pseudoalteromonas ruthenica sp. nov., isolated from marine invertebrates. Int J Syst Evol Microbiol 52, 235-240.

Ivanova, E. P., Shevchenko, L. S., Sawabe, T., Lysenko, A. M., Svetashev, V. I., Gorshkova, N. M., Satomi, M., Christen, R. \& Mikhailov, V. V. (2002c). Pseudoalteromonas maricaloris sp. nov., isolated from an Australian sponge, and reclassification of [Pseudoalteromonas aurantia] NCIMB 2033 as Pseudoalteromonas flavipulchra sp. nov. Int J Syst Evol Microbiol 52, 263-271.

Ivanova, E. P., Sawabe, T., Lysenko, A. M., Gorshkova, N. M., Hayashi, K., Zhukova, N. V., Nicolau, D. V., Christen, R. \& Mikhailov, V. V. (2002d). Pseudoalteromonas translucida sp. nov. and Pseudoalteromonas paragorgicola sp. nov., and emended description of the genus. Int J Syst Evol Microbiol 52, 1759-1766.

Leifson, E. (1963). Determination of carbohydrate metabolism of marine bacteria. J Bacteriol 85, 1183-1184.
Marmur, J. \& Doty, P. (1962). Determination of the base composition of deoxyribonucleic acid from its thermal denaturation temperature. J Mol Biol 5, 109-118.

Mikhailov, V. V., Romanenko, L. A. \& Ivanova, E. P. (2002). The genus Alteromonas and related Proteobacteria. In The Prokaryotes, 3rd edn, release 3.10. Edited by M. Dworkin, S. Falkow, E. Rosenberg, K.-H. Schleifer \& E. Stackebrandt. New York: Springer.

Owen, R. J., Hill, L. R. \& Lapage, S. P. (1969). Determination of DNA base compositions from melting profiles in dilute buffers. Biopolymers 7, 503-516.

Rainey, F. A., Ward-Rainey, N., Kroppenstedt, R. M. \& Stackebrandt, E. (1996). The genus Nocardiopsis represents a phylogenetically coherent taxon and distinct actinomycete lineage: proposal of Nocardiopsaceae fam. nov. Int J Syst Bacteriol 46, 1088-1092.

Romanenko, L. A., Zhukova, N. V., Rohde, M., Lysenko, A. M., Mikhailov, V. V. \& Stackebrandt, E. (2003). Pseudoalteromonas agarivorans sp. nov., a novel marine agarolytic bacterium. Int J Syst Evol Microbiol 53, 125-131.

Sawabe, T., Tanaka, R., Iqbal, M. M., Tajima, K., Ezura, Y., Ivanova, E. P. \& Christen, R. (2000). Assignment of Alteromonas elyakovii $\mathrm{KMM} 162^{\mathrm{T}}$ and five strains isolated from spot-wounded fronds of Laminaria japonica to Pseudoalteromonas elyakovii comb. nov. and the extended description of the species. Int J Syst Evol Microbiol 50, 265-271.

Smibert, R. M. \& Krieg, N. R. (1994). Phenotypic characterization. In Methods for General and Molecular Bacteriology, pp. 607-655. Edited by P. Gerhardt, R. G. E. Murray, W. A. Wood \& N. R. Krieg. Washington, DC: American Society for Microbiology.

Stackebrandt, E. \& Goebel, B. M. (1994). Taxonomic note: a place for DNA-DNA reassociation and 16S rRNA sequence analysis in the present species definition in bacteriology. Int J Syst Bacteriol 44, 846-849.

Svetashev, V. I., Vysotskii, M. V., Ivanova, E. P. \& Mikhailov, V. V. (1995). Cellular fatty acids of Alteromonas species. Syst Appl Microbiol 18, 37-43.

Wayne, L. G., Brenner, D. J., Colwell, R. R. \& 9 other authors (1987). International Committee on Systematic Bacteriology. Report of the ad hoc committee on reconciliation of approaches to bacterial systematics. Int J Syst Bacteriol 37, 463-464.

Wink, J. M., Kroppenstedt, R. M., Ganguli, B. N., Nadkarni, S. R., Schumann, P., Seibert, G. \& Stackebrandt, E. (2003). Three new antibiotic producing species of the genus Amycolatopsis, Amycolatopsis balhimycina sp. nov., A. tolypomycina sp. nov., A. vancoresmycina sp. nov., and description of Amycolatopsis keratiniphila subsp. keratiniphila subsp. nov. and A. keratiniphila subsp. nogabecina subsp. nov. Syst Appl Microbiol 26, 38-46.

Yaphe, W. \& Baxter, B. (1955). The enzymatic hydrolysis of carrageenan. Appl Microbiol 3, 380-383.

ZoBell, C. E. \& Allen, E. C. (1935). The significance of marine bacteria in the fouling of submerged surfaces. J Bacteriol 29, 239-251. 